\title{
Correction: Bashir et al. Determinants of Nonindustrial Private Forest Owners' Willingness to Harvest Timber in Norway. Forests 2020, 11, 60
}

\author{
Altamash Bashir ${ }^{1, *(D)}$, Hanne K. Sjølie ${ }^{1}$ and Birger Solberg ${ }^{2}$ \\ 1 Faculty of Applied Ecology, Agricultural Sciences and Biotechnology, Inland Norway University of Applied \\ Sciences, 2400 Koppang, Norway; hanne.sjolie@inn.no \\ 2 Faculty of Environmental Sciences and Natural Resource Management, Norwegian University of Life \\ Sciences, 1433 Ås, Norway; birger.solberg@nmbu.no \\ * Correspondence: altamash.bashir@inn.no
}

\section{check for}

updates

Citation: Bashir, A.; Sjølie, H.K.; Solberg, B. Correction: Bashir et al. Determinants of Nonindustrial Private Forest Owners' Willingness to Harvest Timber in Norway. Forests 2020, 11, 60. Forests 2021, 12, 1368. https://doi.org/10.3390/f12101368

Received: 16 September 2021 Accepted: 29 September 2021 Published: 9 October 2021

Publisher's Note: MDPI stays neutral with regard to jurisdictional claims in published maps and institutional affiliations.

Copyright: (c) 2021 by the authors. Licensee MDPI, Basel, Switzerland. This article is an open access article distributed under the terms and conditions of the Creative Commons Attribution (CC BY) license (https:/ / creativecommons.org/licenses/by/ $4.0 /)$.
We have found some errors in our recently published article [1]. Consequently, the authors wish to make the following corrections to the paper. The errors resulted due to an incorrect interpretation of the direction of significance of the gender variable in the regression models.

Abstract: The two sentences of the Abstract section should now read: "In the linear regression, being a female owner increased the historical timber supply by $1.48 \mathrm{~m}^{3} \mathrm{ha}^{-1}$ year ${ }^{-1}$ compared to male ownership. In the second regression pathway (tobit model), the two variables female forest owner and owning forests for financial objectives triggered the supply of timber by $1.85 \mathrm{~m}^{3} \mathrm{ha}^{-1}$ year $^{-1}$ and $1.25 \mathrm{~m}^{3} \mathrm{ha}^{-1}$ year $^{-1}$, respectively".

\section{Results}

Willingness to Harvest Timber: Regression Analyses.

On page 9 of the original paper, the sentence: "being a male owner increased the timber supply by $1.48 \mathrm{~m}^{3} \mathrm{ha}^{-1}$ compared to female ownership", should state: "being a female owner increased the timber supply by $1.48 \mathrm{~m}^{3} \mathrm{ha}^{-1}$ compared to male ownership".

In the original paper on page $9-10$, the sentence: "In the tobit model being a male forest owner and owning forests for financial objectives elevated the supply of timber by $1.85 \mathrm{~m}^{3} \mathrm{ha}^{-1}$ and $1.25 \mathrm{~m}^{3} \mathrm{ha}^{-1}$, respectively" should state: "In the tobit model being a female forest owner and owning forests for financial objectives elevated the supply of timber by $1.85 \mathrm{~m}^{3} \mathrm{ha}^{-1}$ and $1.25 \mathrm{~m}^{3} \mathrm{ha}^{-1}$, respectively".

In Table 5 of the original paper, the revised values for taxable net wealth should read as 0.197 instead of -0.197 . Revisions did not bring any changes in the text, as the value was non-significant in the model.

\section{Discussion}

In the second paragraph, the Discussion should read as follows: "In general, female forest owners place more emphasis on conservation values than their male counterparts, and hence are less inclined towards harvesting [45]. However, our study observed that for the period of 2003-2012, female forest owners harvested more timber in comparison to male owners". However, compared to male owners, female forest owners have been found to be older across Europe with less competence in forestry [76] and low engagement in practical forestry [75]".

\section{Conclusions}

The two sentences in the Conclusion paragraph should now read: "Our study found that forest owners with economic objectives were more inclined to harvest, and that female owners harvested more than male owners". "This study also identified the owner groups 
that may require special attention from forest policymakers and extension services, such as owners with limited knowledge of forest policy instruments".

\section{Reference}

1. Bashir, A.; Sjølie, H.K.; Solberg, B. Determinants of Nonindustrial Private Forest Owners' Willingness to Harvest Timber in Norway. Forests 2020, 11, 60. [CrossRef] 